KYIV-MOHYLA HUMANITIES JOURNAL

KYIV-MOHYLA SCHOLARLY PEER-REVIEWED JOURNALS

Art Nouveau Ukrainian Architecture in a Global Context

Author(s): Nelia Romaniuk

Source: Kyiv-Mohyla Humanities Journal 6 (2019): 137-148

Published by: National University of Kyiv-Mohyla Academy

http://kmhj.ukma.edu.ua/ 


\title{
Art Nouveau Ukrainian Architecture in a Global Context
}

\author{
Nelia Romaniuk \\ Zhytomyr National Agroecological University, Department of History
}

\begin{abstract}
The article is dedicated to Ukrainian Art Nouveau architecture, which became a unique phenomenon in the development of late nineteenth and early twentieth-century architecture. Along with the reality that architecture in Ukraine evolved as a component of the European artistic movement, a distinctive architectural style was formed, based on the development of the traditions of folk architecture and ornamentation. This style produced much innovation in the shaping, decor, and ornamentation of buildings. Significant contributions to the development of architectural modernism in Ukraine were made by Opanas Slastion, Vasyl Krychevskyi, Yevhen Serdiuk, Oleksandr Verbytskyi, Serhii Tymoshenko, Oleksandr Lushpynskyi, Ivan Levynskyi, Dmytro Diachenko, and others. Ukrainian Art Nouveau architecture was represented by five main architectural styles: modernist, folkloric, rationalist, neo-baroque, and Vienna Secession. Due to an attainment of the possibilities embodied in the constructions, developed techniques, and in the design of interior space and external features - such as walls, roofs, doors and windows, columns and balustrades — this style formed its own expressive system, which included a significant number of socially significant types of buildings (dwellings, schools, hospitals, warehouses, government buildings, places of worship). The styles of Ukrainian architectural modernism have not exhausted their potential and may yet have a continuation in contemporary architecture and that of the future.
\end{abstract}

Key Words: architecture, Ukrainian Art Nouveau, rationalism, secession, construction.

\section{Introduction}

In conditions of the integrative processes of world development and globalization, the need to research historical experiences in all spheres of life of the Ukrainian people intensifies. The architectural heritage of Ukraine is priceless; it is located in world-famous cities: Kyiv, Lviv, Odesa, Poltava, Kharkiv, and others. In the course of its development, Ukrainian architecture experienced the same stylistic epochs of the world architectural process as other European countries. In particular, the Byzantine influence in the architecture of Kyivan Rus of the 1oth-11th centuries, Romanesque style in the 12th century, Gothicism in the 13th-15th centuries, the Renaissance in the 16th-early $17^{\text {th }}$ centuries, the Baroque in the $17^{\text {th }}-18$ th centuries, classicism at the end of the 18th-first half of the 19th centuries, the so-called style of eclecticism in the 
second half of the 19th century, the modern style of the first half of the 2oth century, the constructivism of the 1920s, and the postconstructivism of the 1930s and 1950s. And in modern times, the architectural process in Ukraine is also in tune with global trends.

During all stages the architecture of Ukraine had significant features, although its national features were most profoundly manifested in Art Nouveau. Therefore, a deeper investigation and understanding of the Ukrainian architectural modern style with its primal background of folk architecture is timely, as many unique findings in form making, décor, and the decoration of buildings appeared.

The development of architectural modernism in Ukraine in the course of forty years (1903-1941) was complex, full of the aspirations of architects to establish themselves, develop local traditions, and rethink them according to the requirements of that time, and to create new forms, which would combine national and international features. At each stage this development revealed its peculiarities, versatility, and variety of styles, which are embodied in the typology of buildings, their composition, and decor.

In the conditions of a totalitarian system, artists of Ukrainian architectural modernism suffered undeserved criticism, humiliation, and discreditation. The best examples of this style of the end of the 19th century and the beginning of the 2oth centuries were not objectively explored and were suppressed, thus hampering its further development. The criticism of Ukrainian architectural modernism continued in the post-war period, in particular, in the publications of Heorhii Lebedev, Mykhailo Tsapenko, Volodymyr Zabolotnyi, Petro Yurchenko, Oleksandr Kasianov, and others.

It was only in the 1980s and 199os that attention to previously forgotten memoirs of Ukrainian architectural modernists and their creators increased, specifically in the studies of Volodymyr Yasievych, ${ }^{1}$ Yurii Asieiev, ${ }^{2}$ Volodymyr Tymofiienko, ${ }^{3}$ and Viktor Chepelyk. ${ }^{4}$ Descriptions of some examples of modernist architecture can be found in the Register of Monuments of the History and Culture of Ukraine. ${ }^{5}$ A study by Viktor Chepelyk, which greatly complemented the history of the architecture of Ukraine is also of great significance. The author identified three stages of Ukrainian architectural modernism: 1903-1917, 1920-1930, and 1934-1941; the scholar defined the main styles, provided descriptions of buildings of different uses, and presented biographical portraits of the outstanding masters of Ukrainian architectural modernism.

1 Vladimir Yasevich, Arkhitektura Ukrainy na rubezhe XIX-XX vekov [Architecture of Ukraine at the Turn of 19th-2oth Centuries] (Kyiv: Budivelnyk, 1988). Yurii Aseev, Stiliv arkhitekture Ukrainy [Styles in the Architecture of Ukraine] (Kyiv: Budivelnyk, 1989). Volodymyr Tymofiienko, Zodchi Ukrainy kintsia XVIII-pochatku XX stolit [Architects of Ukraine, Late 18th and Early 2oth Centuries] (Kyiv: NDITIAM, 1999).

4 Viktor Chepelyk, Ukrainskyi arkhitekturnyi modern [Ukrainian Architectural Modern] (Kyiv: KNUBA, 2000).

5 Petro Tronko, ed., Zvid pamiatok istorii ta kultury Ukrainy [Register of Monuments of the History and Culture of Ukraine], book 1, part 1 (Kyiv: URE, 1999). 
Recently, Yurii Biriulov, ${ }^{6}$ Svitlana Bilenkova, ${ }^{7}$ Svitlana Oborska, ${ }^{8}$ Yuliia Ivashko, ${ }^{9}$ and Rostyslava Hrymaliuk ${ }^{10}$ have published scholarly works on the research of architectural modernism in Ukraine. Namely, Svitlana Oborska in her candidate's thesis, entitled The Synthesis of Arts in the Context of Art Nouveau Style, writes: "As Art Nouveau was supposed to be a style that combines beauty and comfort, it never conflicted with the heritage of civilization. It is the adoption of everything new that explains the current relevance of modernism." 11

Along with the onset of the study of the phenomenon of Art Nouveau in Ukraine, least studied is the shaping of this style in the context of city planning and object and element making. Restoration and memorial protection recommendations, as well as their implementation at the level of state bodies, need to be developed.

\section{Findings}

At the turn of the 19th-2oth centuries, a large number of different art objects emerged, which characterized the gap between the ideological and artistic principles of classical art, the traditions of realism and aesthetics, and were called "modernist." The essence of modernism is encrypted in its very title - it is the creation of everything new ("modern" means "new"). In Europe, modernism covers the chronological period from the 19oos to the 1980s. Art Nouveau architecture includes a set of architectural styles of the twentieth century, for which there is a decisive restoration of forms, constructions, and materials, a rejection of styles of the past, and a rational approach to solving the problems of internal spaces.

Features of the architecture of the twentieth century were determined by the influence of a number of factors: intensive urbanization, industrial construction, and urban population growth, which caused the overcrowding of buildings, appearance of multiple stories, the reduction of greenery, etc. Problems not existing during previous ages emerged. Each of the directions in the development of architecture, at its discretion, responded to these problems. In the late 1910s, a group of European

6 Yurii Biriulov, Mystetstvo lvivskoi setsesii [The art of Lviv Secession] (Lviv: Tsentr Yevropy, 2005).

7 Svitlana Bilenkova, Arkhitektura Chernivtsiv XIX-pershoi polovyny XX stolit [Architecture of Chernivtsi of the 1gth-the First Half of the 2oth Centuries] (Chernivtsi: Bukrek, 2009).

Svitlana Oborska, "Syntez mystetstv u predmetnomu seredovyshchi styliu modern

[The Synthesis of Arts in the Context of Art Nouveau Style]" (PhD diss., Kyivskyi natsionalnyi universytet kultury i mystetstv, 2009).

Yuliia Ivashko, "Dosvid teoretychnoho doslidzhennia arkhitektury styliu modern [The experience of theoretical research of modern style architecture]," Arkhitekturnyi visnyk KNUBA 3 (2014): 15-21.

10 Rostyslava Hrymaliuk, "Formuvannia estetychnoi platformy setsesii v ukrainskomu mystetstvi kintsia XIX-pochatku XX st. [Formation of Aesthetic Platform of Secession in the Ukrainian Art of the late 19th-early 2oth Centuries]," Narodoznavchi zoshyty 6 (2014): 1316-27. 
artists, among them Walter Gropius, Charles Le Corbierz, and Ludwig van der Rohe developed a concept of a new style. Architects of modernism believed functionality and utility to be the basis of a new style. A construction, above all, was supposed to meet practical needs, and only then solve artistic tasks. The comfort and convenience of spatial organization is the top priority of the building. Therefore, in modernism there is a new principle of building houses - "from the inside out," that is, internal space is first planned, which forms the appearance of the building.

Modernism is exceptionally constructive. Since interior design was the primary concern in modernist styles, in appearance it inevitably led to the asymmetry of plans and facades and to free multidimensional composition, which fundamentally differs from standard classical buildings. Windows in modernist houses, as a rule, are different in configuration and size, can be located at different levels, based on the structure of the interior space. On the facades, light and shadow were created by front-facing or recessed volumes, colorful materials, large stained-glass surfaces, pilasters, reliefs, and various fantastic ornaments. The building is characterized by a free blueprint, a picturesque balance instead of strict symmetry.

Influenced and interconnected with European modernism, Ukrainian architectural modernism, a distinctive trend in architecture based on the development of the traditions of folk construction and ornamentation, was formed. At the beginning of the 2oth century, Ukraine was under the authority of the Russian and Austro-Hungarian Empires, therefore, Ukrainian Art Nouveau had distinctive features on these territories. The architecture of Western Ukraine was under the influence of the Vienna Secession, and became known as "secession." The combination of folk art and secession was the result of the emergence of the Ukrainian Secession, which had features of Hutsul and Zakopansky folk art. In Central, Southern, and Eastern Ukraine, which were part of the Russian Empire, a national type of the modernist movement was developed "Ukrainian Modernism," which emerged in Poltava.

The peculiarity of Ukrainian Modernism was the creation and use not only of traditional building forms and elements of national art, but also of new architectural forms with a distinct ethnic, aesthetic component - in contrast to many European style trends, which often used elements of classicism and the baroque (as in the German style) or even avoided any traditional details, replacing them with new ones (see works by Antoni Gaudí, Viktor Horta).12

The historical significance of the modern style is in the blending of different arts. Architects of Art Nouveau resurrected the use of frescoes, mosaics, painted glass, and incrustation. Unlike other styles, the modern style proposed new principles of ensemble architecture. If previously ensemble was understood as the use of related style forms, for the modernist architect the dominant method of including buildings

12 Maksym Honcharenko, "Stanovlennia istorychnykh doslidzhen arkhitektury Ukrainy (kinets XIX-pochatok XX stolit) [The Formation of Historical Studies of Architecture of Ukraine (End of the 19th and Early 2oth Centuries)]" (PhD diss., Akademiia obrazotvorchoho mystetstva i arkhitektury, 2000), 93. 
in the urban environment was the consistency of scale, rhythm, and the similarity of volumes and silhouettes of existing and new buildings, that is, the principle of spatial interconnections, as well as the principle of painting-rhythmic composition. ${ }^{13}$

Regional centers for the development of Ukrainian architectural modernism were formed in the cities of Poltava (from 1903), Lviv (from 1904), Kharkiv (from 1909), and Kyiv (from 1907). Significant contributions were made by Slastion, Krychevska, Serdiuk, Verbytskyi, Tymoshenko, Lushpynskyi, Levynskyi, Diachenko, and others.

The Ukrainian architectural modern style represented six stylistic trends: 1) modernistic trends had become widespread in all regions, pan-European features prevailed in it over national or local peculiarities; 2) folkloric style was marked by decorative-romantic tendencies, based mainly on the development of modernized folk traditions; 3) rationalistic style was marked by restrained forms, deprived of excessive decorative elements; 4) the neo-baroque trend included modernized UkrainianBaroque and folk traditions; 5) secession style was developed in Western-Ukrainian lands; 6) the neo-classical style witnessed an attempt to combine modern folk traditions with classical principles, gaining popularity in the 1930s. ${ }^{14}$

The Ukrainian architectural style includes various types of buildings: dwellings, schools, hospitals, educational, cooperative and trade, agricultural science institutions, administrative, industrial, commerce, religious, exhibition and museum buildings. All this indicates a significant variety of types of buildings and structures designed not to meet the needs of elite groups, but for their use by a broad strata of the people. Of great importance in the formation of Ukrainian architectural modernism were the discussions that took place in connection with competitions or the construction of specific objects, in particular, in 1903-1905 during the design and construction of the Poltava Regional Zemstvo; 1908-1910 during competitions for the construction of the Ukrainian Theater in Lviv; 1911-1913, during competitions for the building of the Kharkiv Art School; 1912-1914, and also from 1927 to 1929, when the discussion about the attitude towards the Ukrainian Baroque continued.

A classic example of Ukrainian architectural modernism was the house "with Chimeras" on Bankova Street, by architect Vladyslav Horodetskyi. Built in 1901-1903 in the expressive style of neo-romanticism, it was a transitional type of building, inbetween a private residence and a commercial property. The exterior of the house created a single ensemble with refined modern interiors. The facade was decorated with columns crowned with a plastic composition of exotic animals, intended to demonstrate the advantages of new building materials and technologies. ${ }^{15}$

A peculiar and unique feature of Ukrainian architectural modernism, which expressed the national preferences and traditions of Ukrainians formed over the centuries, was folklore style. In their projects, architects used a prototypical classical village house, a bell tower, or a wooden church. Construction of buildings to a large

\footnotetext{
13 Oborska, Syntez mystetstv, 3.

14 Chepelyk, Ukrainskyi arkhitekturnyi modern, 41.

15 Aseev, Stiliv arkhitekture Ukrainy, 72.
} 
extent featured traditional solutions (brick walls and wooden floors). However, new solutions were also featured, with gravity to weight reduction and the use of reinforced concrete and metal. Trapezoidal windows and door frames acquired the designation of the most characteristic manifestations of the style. Decorative ornaments on the facades looked like ceramic inserts with colored ornaments. The designs featured combinations of flowers and birds, and elements of heraldry. In some cases, these motifs grew into picturesque panels, repeating samples of folk art, which were formed in the process of the creation of traditional house paintings and embroideries. The use of carving was widespread in the design of doors, windows, balconies and galleries, as well as in metal-plastic materials, in particular, in spaces that decorated the towers or roofs of spires. The characteristic features of this style were found in the decoration of roofs, which mostly had a high four-slope shape and resembled the shape of the roofs of village houses. Tower-shaped elements were also often decorated by pyramidal roofs, sometimes with cavities or pear-shaped domes, even with cupolas.

The folk-oriented trend of Ukrainian modern art includes: the building of the Poltava Regional Zemstvo (1903-1908, architect Vasyl Krychevskyi); a chapel on the battlefield of Poltava (1911-1912, architect Ihor Kalbus); the residential building of engineer Volodymyr Khrennikov in Dnipro (1909-1911, architect Petro Fetisov); an art school in Kharkiv (1911-1913, architect Kostiantyn Zhukov); the houses of Boiko and Popov (1911-1913, architect Serhii Tymoshenko); Nosivka plant breeding station in Chernihiv region (1911-1912, architect Yevhen Serdiuk); a school in Komertsiinyi Lane in Kyiv (1912, architect Vasyl Korobtsov), a hospital in Lubny (1913-1915, architect Dmytro Diachenko), and others.

The first marvel of Ukrainian national-style architecture was the "guest house" in Lebedintsi, built in 1854-1856 and designed by St. Petersburg Academician Yevhen Chervinskyi, on the order of Hryhorii Halahan. This is the first example of architecture that combines traditional folk and new rationalist initiatives. The building featured what was best in the spatial composition and decor of houses as well as rational structural planning based on a new understanding of the functions of rooms and their positional connections.

Ukrainian architectural modernism originated under the influence of several figures who made a significant contribution to its development. Among them, a special contribution was made by the talented architect Vasyl Krychevskyi (1872-1952), who developed a national architectural tradition, giving ethnic color to new types of public buildings. The most impressive example of the Ukrainian architectural style by Krychevskyi, full of deep historicism, is embodied in the building of the Poltava Regional Zemstvo (1903-19o8). It was a multifunctional building. In order to perform administrative functions, there were offices and reception rooms. A large hall was intended not only for holding official meetings, but for public meetings and even concerts as well. An ethnographic museum was created in its central outdoor wing and there was a small hotel in the attic. ${ }^{16}$ 
A granite base, a golden-colored wall, large arched and trapezoidal wall openings, ornaments of blooms above the windows and on the walls, colorful subsalt friezes with rosettes, revealing the theme "May you and we be happy!" - all this impressed with its filigree-painted forms. The facades between the windows featured coats-of-arms of Cossack regiments of the Poltava region, which testified to the history of Hetman rule. The main entrance of the house is distinctive because of its large hexagonal trapezoidal loggia, the side walls of which are decorated with "vase" ornaments and oak carved doors decorated by an image of the "tree of life" — a symbol of the flourishing continuity of generations. The light walls of the lobby were decorated with wreaths and drawn thread work. An even more magnificent view is provided by the hall staircase, where white marble stairs lead to the second floor, where, like an honor guard, there are quadrangular columns with "flowers of life." A large meeting room decorated with ornaments and paintings by artists Serhii Vasylkivskyi and Mykola Samokysh, expressing national and patriotic content, proclaim the ideas of democratic self-government ("The Election of Colonel Pushkar"), the protection of the native land ("The Kozak Holota"), and economic and trade ties ("The Romodan Trade Route"). ${ }^{16}$

The main theorist, inspiration for and practitioner of the Ukrainian architectural style was Opanas Slastion (1855-1933), who in every way contributed to the spread of this style and architectural creativity. Slastion joined the architectural process creating public village buildings using trends of folk architecture. A significant example is the building of the rural credit and cooperative consumer society in Ustivitsa (1909); its peculiar features stand out in the panorama of the village with a tent roof, a spire which is crowned with an agricultural production emblem - a combined rake and scythe. In his next project, a rural consumer cooperatives store in the village of Velyka Bahachka (1910), Slastion used hexagonal trapezoid windows and a tower with a spire, on which an iron crane symbolizes prosperity. In the house of the credit-cooperative and educational society, which he built in the village of Khomutets along with engineer Mykhailo Yelahin in 1912, a more advanced composition is demonstrated, which features the expressiveness and iconic forms of the Ukrainian style while preserving great expediency and resourcefulness. Even more expressive in stylistic qualities was the building of a credit cooperative and academic society in the village of Velyki Sorochyntsi (1913). $\cdot^{17}$

The master's next outstanding project was the creation of a series of zemstvo schools (1913-1916). They were also given a national flavor. These school projects were implemented in more than thirty villages of the Poltava region, in particular in the villages of the present Lokhvytskyi, Lubenskyi, Chornoukhovskyi, and Khorolskyi regions. Comfortable and expressive in artistic terms, they had walls adorned with brick ornamentation, trapezoidal windows, roofs with cavities, and high spires over the towers, which emphasized the main entrances to the schools. In this way, the architect emphasized the importance of the school as an educational center of the village. An 
example of the construction of these schools caused a number of borrowings and repetitions in other areas, in particular, in the Cherkasy, Kyiv, and Mykolayiv regions.

In 1913, Opanas Slastion also developed a series of hospital buildings, outpatient clinics, and residential buildings for physicians. The most significant work was a complex of buildings for the Myrhorod sanatorium. The original design was developed by architect Volodymyr Zuiev, doctor A. Chaushanskyi, and engineer Mykhailo Yelahin (1916-1918). Slastion was invited to give these buildings "Ukrainian stylistic charm." A grand hydropathic clinic dominated the entire complex, thanks to its central part, with a high tower crowned with a spire. In front of this building was a dining hall-club, in which large windows and even a tiny turret with a spire integrated the theme dictated by the hydropathic clinic. Closer to the river was a mud bath clinic, which also featured the dominant theme of expression, but without towers. The image of this hospital resort became widely popular on postcards, bottle labels, and stamps, which provided popularity for the architectural form and became testimony of the recognition of the Ukrainian modern style. ${ }^{18}$

The Ukrainian rationalist modern style differed because of its emphasis on the issues of function and tectonic truth, which created more restrained compositions with less use of décor and flat facade plasticity, with much less enthusiasm for romantic attributes in the form of towers, decorative domes, etc. The rationalistic features of modernism are most clearly manifested in the works of Oleksandr Verbytskyi, and are characterized by a logical pattern of architectural thinking, functional justification of the object, comprehension of the possibilities of new structures, and colorfulness of decoration. ${ }^{19}$

This trend is best represented by the following structures: Ivan Kotliarevskyi school in Poltava (1903-1905, architects Yevhen Serdiuk and Mykhailo Stasiukov), the Bessarabskyi indoor market, Kyiv (1910, architect Henryk Gaj, engineer Mykhailo Bobrusov), Serhii Hrushevskyi's school in the Kurenivka district of Kyiv (1908-1910, architects Volodymyr Krychevskyi and Eduard Bradtman), a breeding station in Kharkiv (1909-1912, architect Yevhen Serdiuk), a complex of cooperative residences in Odessa (1911-1912, architect Yakiv Ponomarenko), a "Prosvita" building in Manuilivka, near Dnipro (1909-1910), a credit cooperative society in Velyki Sorochyntsi (1913, architect Opanas Slastion), Yurkevych's house on 8, Pankivska Street in Kyiv (1914, architect M. Shehonin), the Kyiv purification station in Saperna Slobidka (1914), and a residential building on 9, Kudriavska Street in Kyiv (1912-1913, architects Vasyl Krychevskyi, Pavlo Maziukevych).

The Ivan Kotliarevskyi school in Poltava was founded during festivities coinciding with the unveiling of a monument of the author of the Eneida. The school was built in 1903-1905 by architects Yevhen Serdiuk and Mykhailo Stasiukov on donations from Poltava community organizations. It was a two-story building, the restraint of form of

18 Chepelyk, Ukrainskyi arkhitekturnyi modern, 293.

19 Roman Vechirko, Ukrainska ta zarubizhna kultura [Ukrainian and Foreign Culture]

(Kyiv: KNEU, 2003). 
which determined the rationalist character of its architecture, was due to insufficient funds. The asymmetrical composition of the building on the main facade had an important attraction - the bust of Ivan Kotliarevskyi, executed by sculptor Leonid Pozen. The corners of the left-side avant-corps were decorated with majolica arabesques.

New rationalistic and traditional initiatives were combined in the building of the Zhytomyr Regional Library for Children (formerly the Zhytomyr Public Library). The decoration of the facade includes dimensional decorative geometric ornaments and rhythmic strips of tiles, which significantly enliven it. Tower-like asymmetrical projections decorate the pyramidal roof with a complex step structure that harmoniously complement each other and decorate the facade of the house. Another example of Zhytomyr Art Nouveau is the local History Museum. The facade of the building is decorative and romantic and is dominated by white and blue colors. In many of the decorated facades of the paired window arches of the second tier the decor has a particularly complex appearance, due to the presence of straight and wave-shaped relief strips in it. The plaster alternates between the smooth roughness of its varieties, complemented by molded ornaments in the form of lush and chaotic scattered flowers, which are located on its plane. The triangular pediments of the side rails emphasize the central part of the facade of the building and its main axis. A refined floral ornament surrounds different parts of the house.

Restraint, asceticism, the minimization of decoration, and mostly geometrical forms were characteristic for the rationalist modernism of the 1920s-1930s. Among the key works of this period are the following buildings: the Myroniv Selection Station, residential complexes of the Kharkiv tractor plant, residential areas in Makiivka and Kamianske, engineering constructions in Bila Tserkva and Kryvyi Rih, buildings of the city council in Tulchyn, a sanatorium in Myrhorod, railway stations in Kyiv and Novomoskovsk, a hotel in Kaniv, and the interiors of many public buildings in Kyiv and Kharkiv. Of these works, the works of Pavlo Aloshin, Viktor Trotsenko, Volodymyr Krychevskyi, Dmytro Diachenko, Mykola Damilovskyi, Oleksandr Verbytskyi, and others are publicly recognized.

An outstanding example of rationalist modernism built in 1908-1912 is the Bessarabskyi market in Kyiv (architect Henryk Gaj). It became the first open market in Ukraine that met modern standards: an original hinge structure, latest technological equipment that allowed the storage of products, a water supply, ventilation, and heating. Metal arches, large glass display-windows, hall height (32 meters at the center), impressed with their grandeur and demonstrated new materials and technologies. The facade of the building is decorated with large windows of traditional and arched form, reliefs by sculptors Tetiana Rudenko and Oleksii Teremets, forged flowers, and ornaments made of bricks. The building impresses with the high quality of its construction work, functional solutions, professionally embodied proportions, and discreet decor in the Ukrainian style. ${ }^{20}$ 
The features of rationalism were even more prominent at the late stage of Ukrainian architectural modernism, from 1934 to 1941. Hexagonal slots are rarely used, roofs are simplified, yet brick wall decoration to some extent gives an exotic feature to this trend. Notable works of the late 193os include Taras Shevchenko museums in Kaniv and Shevchenkove village, trade kiosks, the "Riviera" restaurant, buildings of shoe factory number 4 in Kyiv, the "Ukrainian Book" store in Moscow, residential buildings in the "Chervona Bavaria" village in Kharkiv, and the student hostel of the Kyiv Engineering and Construction Institute. The following architects worked on these projects: Volodymyr Krychevskyi, Petro Kostyrko, Oleksii Tatsii, Anatolii Dobrovolskyi, Dmytro Diachenko, Noi Pidhirnyi, and others. ${ }^{21}$

The secession style that emerged in Western Ukrainian regions combined elements of modern and folk architecture of the Ukrainian West. Secession as a nationally oriented style in architecture testified to the growth of the national consciousness of the Ukrainian population in Western Ukrainian regions at the beginning of the 2oth century. It is precisely in secession that new life is acquired not only in form but also in the principles of formation, characterized by the baroque style, which resulted in a significant number of monuments, especially in western Ukrainian cities. Like the Baroque style, secession sought to harmonize the unity of people and nature - this was reflected in the peculiar "biological romanticism" of secession, in the cult of the organic world, and in the domination of the idea of a comprehensive vital energy in its formallyshaped structure. Curvilinear forms, wave-like arabesques, principles of asymmetry, the transfer of the dynamism of motion and rhythm, and the creative interpretation of natural models of the baroque found an organic reflection and continuation in the Ukrainian secession. ${ }^{22}$

A typical example of the Ukrainian secession is the premises of the Dnister Bank in Lviv, built in 1905-1906 (architect Ivan Levynskyi et al). Its silhouette resembles traditions of the folk architecture of the Carpathians; the structure is decorated with stucco and majolica, influenced by Hutsul ceramics. A deeply patriotic orientation of style is embodied in the building of the pedagogical society in Lviv (architects Ivan Levynskyi, Oleksandr Lushpynskyi, Tadeusz Obmiński, among others), in which plastic forms of the affirmation of the idea of national identity are filled with testimonials of heroic times of struggle, depicted in high and tower-like dominants. Art Nouveau style is also featured in the buildings of the musical college on Shashkevych Street (1916, architects Ivan Levynskyi, Oleksandr Lushpynskyi) and a residential house on Taras Shevchenko Avenue (1905, architects Tadeusz Obmiński, Michał Ulam, Zygmunt Kędzierski).

The following structures were built in the style of ornamental secession: house no. 4, the former Trade House of engineer Jan Stromenger in General Hryhorenko square (1906, architect Tadeusz Obmiński); building no. 3, the former property of R. Papée on Academic Oleksandr Bohomolets Street (1906, architect Ivan Levynskyi);

21 Chepelyk, Ukrainskyi arkhitekturnyi modern, 26. 
and building no. 2, built for former owner Jan Lange on Academic Ivan Pavlov Street (architect Tadeusz Obmiński, 19o6). Modernized traditions of Hutsul folk architecture characterize the Solsky Hospital building in Lviv (architect Oleksandr Lushpynskyi). ${ }^{23}$

Current problems in the development of architecture in Ukraine include a lack of the expression of formative solutions due to technology, corporate standards, conservative tastes, and individual requests, which encourage the implementation of the best examples of historical heritage, in particular of Ukrainian architectural modernism. In the 21st century, the epoch of technological domination and expediency, the modern style with its cult of beauty and expediency is always contemporary. The fairy tale of classical modern art is organically integrated into the apartments of modern high-rise buildings and suburban homes. The modern interior in the modernist style harmoniously combines regal wood, metal, colored glass, expensive fabrics, ceramics, stone, forged elements, mirrors, and stained glass windows. The design of the modern interior is characterized by functional solutions and a strict adherence to its requirements, compact volumes with clearly defined frames, the technical clarity of forms, and a lack of moulded decoration. Built-in niches and backlighting are widely used. In domestic practice, exterior and interior projects use Ukrainian modernist motifs, presented in a stylized form. ${ }^{24}$

\section{Conclusion}

The research of Ukrainian architectural modernism shows its significance and role in a global context and in global architecture. This style has developed its own expressive morphological system, which encompasses a significant number of socially significant types of buildings (dwellings, schools, hospitals, commercial, administrative, and religious buildings) due to the comprehension of opportunities that were established in modern constructions, in techniques that were developed to design internal space and external elements - walls, roofs, doors and windows, columns, and balustrades. The essence of the style emphasizes bright imagery, peculiar coloring, and decorations embodied in wood, ceramics, reinforced concrete, and metal. All of this characterizes the profound identity of a Ukrainian architectural style worthy of imitation. The styles of Ukrainian architectural modernism have not exhausted their potential and can have their continuation in contemporary and future architecture.

\section{Bibliography}

Aseev, Yurii. Stili v arkhitekture Ukrainy [Styles in the Architecture of Ukraine]. Kyiv: Budivelnyk, 1989.

23 Hrymaliuk, Formuvannia estetychnoi platformy setsesii, 1317-18.

24 Svitlana Oborska, "Syntez mystetstv u predmetnomu seredovyshchi styliu modern [Synthesis of Arts in the Context of Art Nouveau Style]" (Avtoreferat dysertatsii kandydata mystetstvoznavstva, Kyivskyi natsionalnyi universytet kultury i mystetstv, 2009), 17. 
Bilenkova, Svitlana. Arkhitektura Chernivtsiv XIX-pershoi polovyny XX stolit [The Architecture of Chernivtsi From the 19th to the First Half of the 2oth Century]. Chernivtsi: Bukrek, 2009.

Biriulov, Yurii. Mystetstvo lvivskoi setsesii [The Art of the Lviv Secession]. Lviv: Tsentr Yevropy, 2005.

Chepelyk, Viktor. Ukrainskyi arkhitekturnyi modern [Ukrainian Architectural Modernism]. Kyiv: KNUBA, 2000.

Honcharenko, Maksym. "Stanovlennia istorychnykh doslidzhen arkhitektury Ukrainy (kinets XIX-pochatok XX stolit) [The Formation of Historical Studies of the Architecture of Ukraine (End of the 19th-to the Beginning of the 2oth Century)]." PhD diss., Akademiia obrazotvorchoho mystetstva i arkhitektury, 2000.

Honcharenko, Maksym. "Modern v Ukraini. Vasyl Krychevskyi [Modernism in Ukraine: Vasyl Krychevskyi]." Osvita rehionu 3 (2016): 90-4.

Hrymaliuk, Rostyslava. "Formuvannia estetychnoi platformy setsesii v ukrainskomu mystetstvi kintsia XIX-pochatku XXst. [The Formation of the Aesthetics of the Secession in Ukrainian Art (End of the 19th-to the Beginning of the 2oth Century)]." Narodoznavchi zoshyty 6 (2014): 1316-27.

Ivashko, Yuliia. "Dosvid teoretychnoho doslidzhennia arkhitektury styliu modern [The Practice of Theoretical Research on the Modernist Architectural Style]." Arkhitekturnyi visnyk KNUBA 3 (2014): 15-21.

Oborska, Svitlana. "Syntez mystetstv u predmetnomu seredovyshchi styliu modern [Synthesis of the Arts in the Context of the Modernist Style].” PhD diss., Kyivskyi natsionalnyi universytet kultury i mystetstv, 2009.

Skibitska, Tetiana. Kyivskyi arkhitekturnyi modern (1900-1910 roky) [The Kyivan Architectural Modernism, 190os-1910s]. Lviv: Tsentr Yevropy, 2011.

Tronko, Petro, ed.Zvid pamiatok istorii ta kultury Ukrainy [Register of Monuments of the History and Culture of Ukraine]. Book 1. Kyiv: URE, 1999.

Tymofiienko, Volodymyr. Zodchi Ukrainy kintsia XVIII-pochatku XX stolit [Architects of Ukraine of From the Late 18th to the Early 2oth Century]. Kyiv: NDITIAM, 1999.

Vechirko, Roman. Ukrainska ta zarubizhna kultura [Ukrainian and Global Culture]. Kyiv: KNEU, 2003.

Yasevich, Vladimir. Arkhitektura Ukrainy na rubezhe XIX-XX vekov [The Architecture of Ukraine at the Turn of 19th-2oth Centuries]. Kyiv: Budivelnyk, 1988.

Nelia Romaniuk, Doc. Hab., is a professor of history at Zhytomyr National Agroecological University. She defended her doctoral dissertation on the agricultural sector during the modernization in Ukraine (1861-1914). Dr. Romaniuk has more than 8o scholarly works and has participated in international and Ukrainian conferences. Her scholarly interests are focused on the issues pertaining to Ukrainian history and culture. She is the recipient of an award for excellence in education in Ukraine. 